\title{
Science in Australasia
}

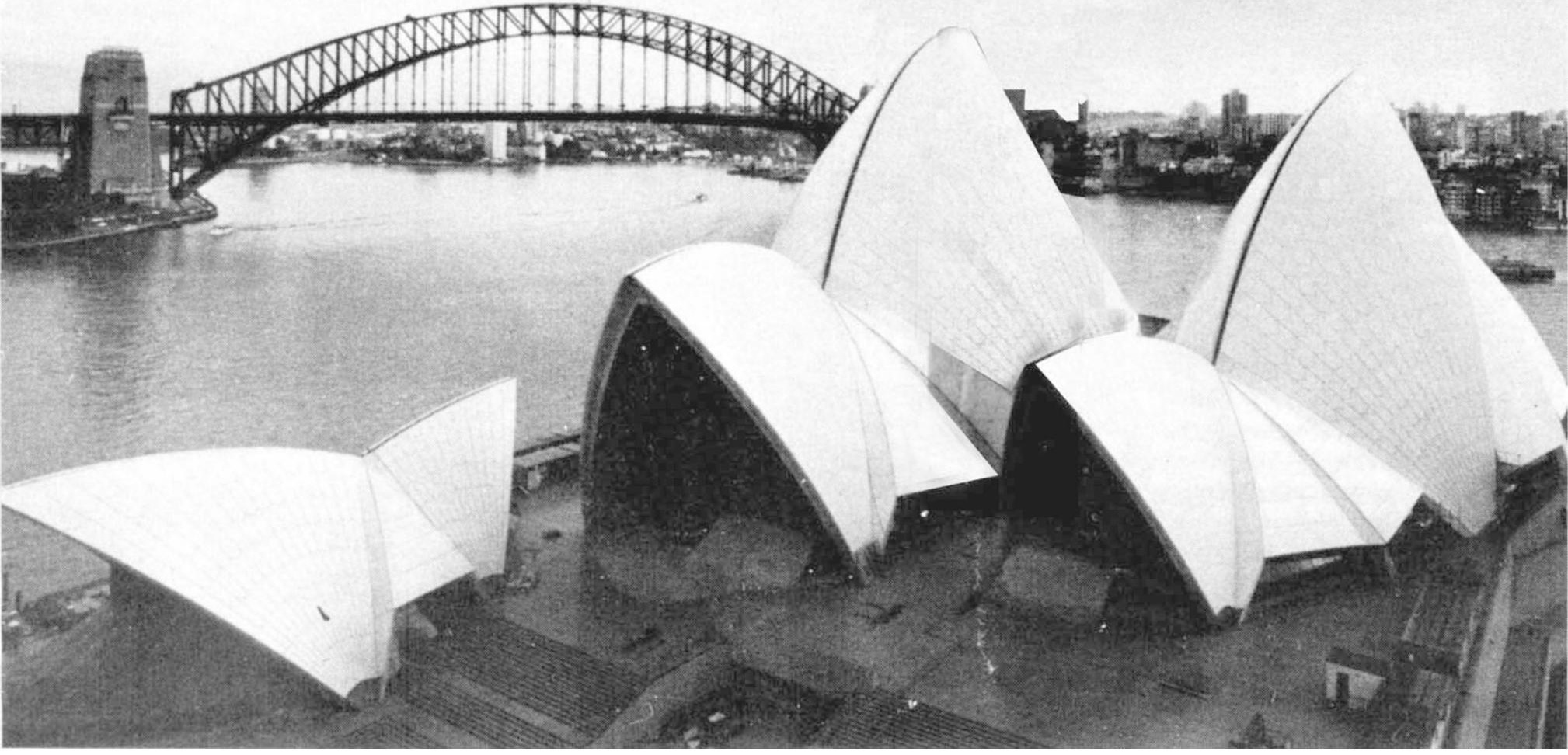

Sydney Opera House [Australian Information Service]

In the following pages a few of those closely concerned review some of the science being done in Australia and New Zealand and look at the way in which the two countries support their scientists. There is one aspect of Australasian science, however, which deserves some comment but which can only be a matter of personal opinion.

In 1836 Charles Darwin wrote of New Zealand: "I believe we were all glad to leave; it is not a pleasant place and the greater part of the English there are the very refuse of Society'; and of Australia: "Farewell, you are a rising infant and doubtless some day will reign a great princess, but you are too great and ambitious for affection, yet not great enough for respect.' Australasians have always been sensitive to the attention they receive from the rest of the world, particularly from the Europe-North America axis, and are keen to know whether they are now regarded with affection and respect and deemed to live in a pleasant place.

This concern has very realistic roots for scientists. Australasia is not a natural break in anyone's journey. It is not widely known either for unusually generous financial support of its scientists or for academic cloisters steeped in tradition. Journals arrive late, preprints are harder to come by and telephone calls to co-workers are not the casual affairs they can be elsewhere. There are thus reasons why scientists may not think seriously of ever visiting the area, let alone working there.

To this geographical isolation one has had to add a degree of self-cultivated philistinism amongst Australians. (Hereafter we speak of Australia rather than Australasia because of a more limited knowledge of New Zealand.) A.J. Marshall described their principal pastimes at the time of Darwin's visit as rum, horse racing and cricket, and it is a common belief beyond Australian shores that the same is still true. Australians are said to suffer from 'cultural cringe' - a desire to appear like sophisticated Europeans coupled with an obsessive fear of putting a foot wrong. The Australian image-and outsiders often tend to treat the country as a phenomenon rather than an equal-should not be underestimated as an inhibitor of a free flow of scientists every bit as powerful as the geographical isolation. It is no accident that a majority of scientists live within reach of the cultural centres of the Northern Hemisphere.

All this is changing rapidly. Obviously the Sydney Opera House can be only a symbol, but by the same token the South Bank in London was also a symbol which has played a large part in the English cultural renaissance. Good news is heard on many fronts; there are new theatres and concert halls in Perth, Brisbane, Adelaide and Sydney. After many years in which Australian artists, writers and composers left their country to receive recognition, there now appears to be a reversal of the flow. The Australian Council for the Arts has been reorganised to allow professionals rather than rich dilettantes to run the show. It would be wrong to give Mr Whitlam's one-yearold government too much credit for all this; rather, the feeling in the country in favour of cultural change was also one in favour of political change.

If Australians are now making their country more appealing it is also the responsibility of outsiders to help break down the geographical isolation. The scientific community means little if communication between London, Boston and San Francisco is at the expense of that to Tokyo, Calcutta and Canberra. Science, even more than the post office and the airlines, needs more communal activity.

FUNDING AND CONTROL OF AUSTRALIAN SCIENCE NEW ZEALAND'S NATIONAL RESEARCH ADVISORY COUNCIL AND THE USE OF SCIENTIFIC RESOURCES SCIENTIFIC RESEARCH IN NEW ZEALAND

SCIENCE UNDER AN AUSTRALIAN LABOR GOVERNMENT

SEISMOLOGICAL AND GEOTHERMAL RESEARCH IN NEW ZEALAND

EARTH SCIENCES AND THE AUSTRALIAN CONTINENT PEST MANAGEMENT IN AUSTRALIA SOLAR POWER IN THE AUSTRALIAN ENERGY SCENE ROCK ART IN AUSTRALIA

EMERGING PICTURE OF PLEISTOCENE AUSTRALIANS PROSPECTS FOR ASTRONOMY IN AUSTRALASIA 